\title{
I Belong to Everybody yet to Nobody: Pragmatic Acts in President Muhammadu Buhari's Inaugural Speech
}

\author{
By Ayo Osisanwo*
}

\begin{abstract}
An inaugural speech, which expresses the agenda of an elected candidate's reaffirmation of the electioneering campaign promises and the goals, is made on the occasion of official inauguration or swearing-in of the candidate. Speeches of presidents and heads of states have always been subjected to linguistic and non-linguistic analyses. However, President Muhammadu Buhari's Inaugural Speech has not enjoyed much documented analysis because it was recently delivered. This paper, therefore, investigates the use of words by the president from a pragmatic perspective in order to identify the pragmatic acts involved and the goals of the acts. Applying aspects of Jacob Mey's (2001) pragmatic acts theory for descriptive analysis, and statistical details for quantitative analysis, nineteen practs were identified from the total of ninety-nine (overlapping) acts found in the speech, and were meant to achieve four goals. While proposing, promising, stating and assuring achieved the goal of revealing intention; acknowledging, thanking, remarking, saluting achieved the goal of admitting and appreciating; appealing, reminding, instructing/calling, advising, hoping, charging, informing, extending achieved the goal of direction/directives; and identifying, describing and defining achieved the goal of giving details on issues. In addition, the pragmatic acts were marked with some pragmatic tools, including shared situation knowledge, relevance, reference, inference. This paper adds to the understanding of rhetoric and the political agenda of President Muhammadu Buhari.
\end{abstract}

Keywords: inaugural speech, language of politics, Muhammadu Buhari, pragmatic acts.

\section{Introduction}

Presidents of nations all over the world deliver speeches as a response to particular national events, such as inauguration of a new administration, Independence Anniversary, Democracy Day, Workers' Day, among others, depending on the import of different days to different countries. The office of the president, despite being the highest office in any country, needs constant link with the people, and speech making serves to establish a link between the president and the citizenry. Therefore, the presidential speech is an evocation of link or relationship between the president and the society. Hence, the presidential speech evokes "a linguistic activity that establishes the relationship between the president, the society and its members" (Nedashkivska, 2006, p. 41). In the Nigerian situation, the inaugural speech is delivered on May 29 (Democracy Day), which has been the hand-over day from one administration to the other in Nigeria since 1999. Under a normal situation, a Nigerian president has the opportunity to deliver at least three Democracy Day speeches and an inaugural speech. While the inaugural speech signifies the inception of a newly elected or re-elected administration, the Democracy Day speech serves to commemorate the restoration of democracy in Nigeria. An Independence Day speech is delivered on October 1

${ }^{*}$ Lecturer, Department of English, University of Ibadan, Nigeria. 
of every year to commemorate Nigeria's independence. A Workers' Day speech is delivered on May 1 of every year to appreciate the contribution of the nation's workforce to the development of the nation. A New Year speech is delivered on January 1 of every year to welcome citizens to the New Year and take a stock of the administration's achievements in the preceding year.

On rare occasions, special speeches are made on emergency situations, involving security situation, national disaster, among others; therefore, the speeches made by a Nigerian president in a year may not be fixed at a particular number. Among the listed speech types, the inaugural speech, which is designed to set the agenda for a new administration, is a speech given during the inauguration ceremony. The word "inauguration" takes its root from the Latin word augur, which refers to the rituals of ancient Roman priests, seeking to interpret for a public official to be deemed worthy to assume office. Inauguration refers to the ceremony which marks the beginning of a newly elected official such as governor, president and so forth. An inaugural speech is a speech delivered at a ceremonial induction of an individual into a new office. At inauguration ceremonies, a political leader takes the oath of office in front of (a large crowd of) spectators. The ceremony marks the beginning of a major public leader's term of office, while the speech informs the people of the leader's intentions in office. The leader's inaugural speech is very significant, and many citizens always look forward to it since it determines the first impression of the leader by the citizenry. The speech often expresses the agenda of the elected candidate, reaffirms the electioneering campaign promises and the goals to achieve in office. It also disseminates information, douses tension generated from the electioneering period, projects into the future and stimulates the citizenry to action. The language of the speech is, therefore, often carefully and skillfully crafted in order to meet the expectations of the citizenry. This is why the present study is interested in the inaugural speech (henceforth, IS) of President Muhammadu Buhari (henceforth, Buhari/PMB) as the fifth elected President of Nigeria.

The election of President Muhammadu Buhari under the umbrella of All Progressives Congress (APC) in 2015 led to the unseating of the People's Democratic Party (PDP). General Muhammadu Buhari was born on 17 December 1942. A retired Army General, PMB was the Head of States in Nigeria from 31 December, 1983 to 27 August, 1985, after taking power in a military coup d'état. He lost, but was the main challenger of the ruling party in each of the general elections held for the office of President in the 2003, 2007 and 2011 general elections. For the three unsuccessful periods, he ran in two different parties (ANPP and CPC) and a third party (APC) in the last election, which he won. He officially took over the office from President Goodluck Jonathan on 29 May, 2015.

Linguists have often studied the use of language to communicate the intentions of the president in inaugural speeches, in order to examine its appropriateness. Hence, a study of the speeches offers a researcher access to the linguistic structures of the texts. Linguists and non-linguists have subjected different speeches, including inaugural speeches and other world leaders' speeches to different analysis. For the purpose of this study, the linguistic aspect is of 
importance. In Nigeria, on the military speeches, studies have been conducted on the stylistic features of war speeches of Yakubu Gowon and Emeka Ojukwu (Oha, 1994); discourse tacts in military coup speeches in Nigeria (Adegbija, 1995); grapho-syntactic features of selected political speeches of some Nigerian military heads of state, like General Murtala Muhammed, General Ibrahim Babangida, Major-General Aguiyi Ironsi and General Olusegun Obasanjo (Ayeomoni, 2005a); on the linguistic-stylistic analysis of political speeches of past Nigerian military rulers (Ayeomoni, 2005b).

On the civilian presidents, scholars have carried out a critical discourse analysis of Nigeria's President Olusegun Obasanjo's speeches (Ayoola, 2005); dysphemisms in the speeches of President Olusegun Obasanjo (Yusuf, 2003); the rhetorical contents of President Olusegun Obasanjo's inaugural speeches (Adetunji, 2006); a comparative pragmatic study of the second election speeches of Nigeria's President Olusegun Obasanjo and America's President George Bush (Adetunji, 2009). Others have also considered adversarial discourse in President Olusegun Obasanjo's labour speeches (Okpanachi, 2009); pragmatic features of the 2007 inaugural address of President Umaru Yar Adua of Nigeria (Olaniyi, 2010; Ayeomoni \& Akinkuolere, 2012); lexical choices and cognition in both the first and second inauguration speeches of Olusegun Obasanjo (Odebunmi \& Oni, 2012); pragmatic features of the inaugural speeches of Presidents Barack Obama of the USA and Goodluck Jonathan of Nigeria (Josiah \& Johnson, 2012). A common decimal in most of the pragmatic analysis of inaugural speeches is the use of Austin and Searle's Speech Act Theory. However, while the present study is interested in the inaugural speech of President Muhammadu Buhari, which has not been worked on because it was recently delivered, the analysis is guided by Jacob Mey's Pragmatic Acts. In the section that follows, we set a background for this study by locating it within the discourse of politics and examine the relationship between language and politics. Then, we discuss the theoretic perspectives in which the analysis is seated, and we present the methodology. Subsequently, we present an outline of the inaugural speech, the analysis and discussion, and finally, the conclusion.

\section{Language and Politics}

Language as a human vocal noise or the arbitrary graphic representation of this noise used systematically and conventionally by members of a speech community for communication purposes (Osisanwo, 2003, p. 1), is indispensable to man. As the faculty of human speech present in all human beings due to heredity (Crystal, 1971, p. 161), language is the main means of communication which distinguishes man from other animals. Since man as a social animal constantly finds himself in an environment where there is a need for communication, language - the main channel through which the patterns of living are transmitted from man to man (Halliday 1978, p. 9) is used to achieve this aim. On the other hand, attempts to arrive at a consensus definition for politics have been a Herculean task since the definition given to it is relative. In everyday usage, 
we can simply say that politics signifies what politicians do, especially that which pertains to the affairs of the state. The etymology of the word "politics" suggests (that is, from Greek polis, city, state) (Joseph, 2006, p. 2). In the words of Chilton (2004, p. 1), politics has been defined as "a struggle for power, between those who seek to assert and maintain their power and those who resist it". The thirst to be in control of power probably explains why there seems to be a lot of contest or struggle between individuals for the one who takes over the mantle of leadership in a particular environment. What therefore is the business of politics and politicians? According to Oha (1994), one of the important, if not the most important, system(s) of communication in politics is language. Politics, which is a public phenomenon, is enabled by language. It is clear that, the concepts of "language and politics" are interwoven. Hence, it will not be out of place to say that politics has become linguistic - a linguistic issue while language has become political - a political issue. Language is a powerful tool of manipulation in the hands of political leaders. Since politics is basically about struggling to control power, language is used to accomplish the control of power, thereby making language a very strong political weapon. It is used to inform, instruct, motivate, persuade, entertain and influence the citizenry. In the same vein, language is used to prepare, accompany, control, guide, explain, justify, evaluate, criticize, and influence politics (Osisanwo, 2009; 2010).

Conscious of the needs of the masses, political leaders become aware of the language to use in pursing their political agenda; they make frantic efforts to address the needs of their audience and win their support through persuasion, an essential communicative fuse in political discourse. Hence, according to Edom (1965) as cited by Adeyanju (2002, p. 532) language is the key to the heart of the people, if you lose it, you lose the people, if you keep it safe, it unlocks the people's heart. This is supported by the view of Opeibi (2009) who emphasises the fact that "No matter how good a candidate's manifesto is; no matter how superior political thoughts and ideologies of a political party may be, these can only be expressed and further translated into social actions for social change and social continuity through the facilities provided by language".

The great significance of politics in everyday life has given political discourse an attractive stature and value among linguists. Linguists have continued to subject it to critical examination. Hence, the present study is equally interested in the functional use of language in the first speech delivered by Muhammadu Buhari as the President and Commander in Chief of the Armed Forces of Nigeria in 2015, upon his inauguration as the fifth elected President of Nigeria.

\section{The Pragmatic Act Theory}

The pragmatic act theory is a theory of pragmatics which was developed by Jacob Mey. It is an amendment to J. L. Austin's (1962) Speech Act Theory (SAT). According to Mey (2001), Austin's Doing Things with Words is merely a theory of reference. Despite Austin's claim that the SAT caters for context, Mey contends that context is more than just reference. Context is action; it is about understanding 
what things are for; it is also what gives our utterances their true pragmatic meaning and allows them to be counted as true pragmatic acts (Mey, 2001, p. 41). Mey (2001, p. 43) argues further that "the context determines what one can say and what one cannot say". Consequent upon the limitation of SAT, Mey proposes the Pragmatic Act Theory as not just a theory of reference but a theory of action which situates speech acts in the appropriate socio-cultural contexts. Mey posits that in order for speech acts to be effective they have to be situated: "they both rely on, and actively create the situation in which they are realized ... there are no speech acts, but only situated speech acts, or instantiated pragmatic acts" (Mey, 2001, p. 218). Consequently, the emphasis is not on conditions and rules for an individual speech act, but on characterising a general situational prototype (pragmeme) that can be executed in the situation. Thus, a particular pragmeme can be substantiated and realized through individual pragmatic acts. In other words, a pragmatic act is an instance of adapting oneself to a context, as well as adapting the context to oneself. Figure 1 is the graphic representation of Mey's (2001) model of pragmatic acts.

Figure 1. Mey's Scheme of a Pragmeme

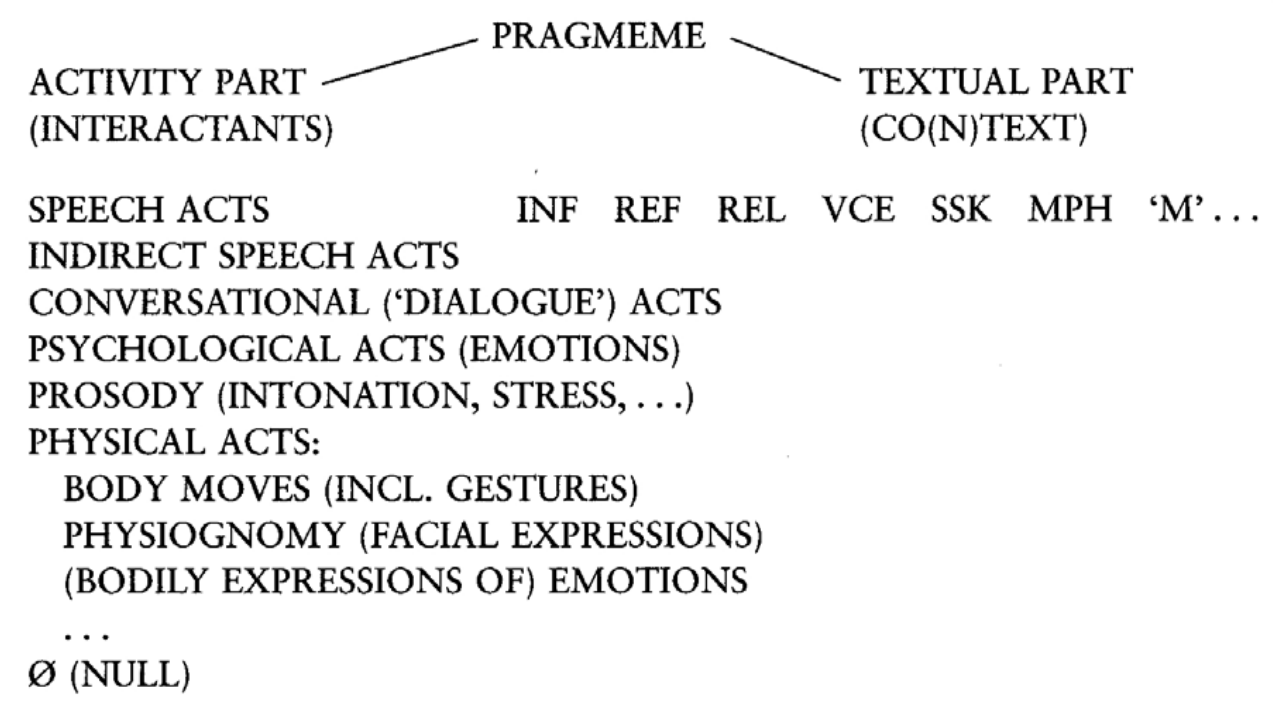

PRACT

ALLOPRACT

PRAGMEME, PRACT, ALLOPRACT

Figure 1 shows that there are two parts to Mey's (2001) theory of a pragmeme: Activity and textual. According to Mey, the activity part, which includes acts that can be performed by interactants in communication, has a list of optional components of the model - it is possible to have one of the components and not the other(s). On the other side, the textual part has a list of components which make the context (or co-text). Whereas the activity part (on the left) covers speech acts, indirect speech acts, conversational ("dialogue") acts, psychological acts, prosodic acts and physical acts, the textual part (on the right) involves context 
elements: INF represents "inference"; REF, "Reference", REL, "relevance"; VCE, "voice"; SSK, "shared situation knowledge"; MPH, "metaphor"; and M "metapragramatic joker". In relation to the present study, components such as speech acts, psychological acts (on the left wing) and INF, REF, REL, VCE, SSK (on the right wing) are of immediate relevance.

\section{Methodology}

In this work, we purposively chose the inaugural speech of President Muhammadu Buhari. The limitation to this speech engendered a thorough analysis. The selected speech was downloaded from the Internet and analysed to show the pragmatic acts in play in the course of delivering the speech. The pragmatic approach adopted for the study is based on aspects of the pragmatic acts theory of Mey (2001). With the title and closing, the speech has just one thousand, nine hundred and forty five (1943) words. Therefore, for a descriptive analysis, we subjected the whole speech to a critical examination and extracted the pragmatic acts (otherwise termed "practs") in each of the sentences. In addition, quantitative analysis, the frequency counts were converted to percentage for statistical analysis.

\section{Outline of the Inaugural Speech}

\section{Paragraph 1}

Thanking God;

Remarking Nigeria's triumph;

Remarking Nigeria's occasion to celebrate her freedom and cherish her democracy. Remarking Nigerians commitment to democracy and determination to entrench its culture.

Remarking the uneasiness of the journey;

Thanking Nigerians;

Thanking Nigerians for their determination;

Paragraph 2

Thanking friends from abroad for their strong support.

Acknowledging his predecessor's statesmanship;

Acknowledging his predecessor's cooperation for a smooth transition process, which has shown good virtues to the world.

Paragraph 3

Acknowledging the cooperation of the former and the new president; Hoping the act of graciously accepting defeat becomes the standard in subsequent elections.

\section{Paragraph 4}

Thanking the millions of his supporters who believed in him even when the cause seemed hopeless;

Saluting/thanking their resolve in waiting for long hours in rain and hot sunshine to register and cast their votes; 
Thanking those who tirelessly carried the campaign on the social media; Thanking the other countrymen and women who did not vote for him but contributed to making the democratic

Paragraph 5 culture truly competitive, strong and definitive.

Reminding all that he just swore by the Holy Book a few minutes earlier. Promising to keep to the oath and serve as President to all Nigerians.

Paragraph 6

Paragraph 7

Proposing/promising to belong to everybody and to nobody.

Acknowledging that a few people are fearful that he might go after them upon assumption as President; Acknowledging the needlessness of the fear; Promising there will be no paying off

Paragraph 8 old scores because the past is prologue.

Assuring the neighbours in the Sub-region and the African brethren that his administration will be ready to play any leadership role that Africa expects of it;

Thanking the governments and people of Cameroon, Chad and Niger for committing their armed forces to fight Boko Haram in Nigeria.

\section{Paragraph 9}

Assuring the wider international community of his readiness to cooperate and help to combat threats of cross-border terrorism and other challenges of the $21^{\text {st }}$ century.

\section{Paragraph 10}

Acknowledging the enormousness of the challenges at home; Stating insecurity, pervasive corruption, the hitherto unending and seemingly impossible fuel and power shortages as his immediate concerns;

\section{Paragraph 11}

Promising to tackle them head on.

Assuring Nigerians that they will not regret that they had entrusted national responsibility to him;

Charging Nigerians not to succumb to hopelessness and

\section{Paragraph 12} defeatism; Promising to fix the problems.

Reminding the Nigerian leaders of the mission of Nigeria. Acknowledging the roles of Nigeria in establishing certain standards of governance.

Stating the observed differences in their methods tactics or details,

Acknowledging the unity in their mission to establish a viable and progressive country. 
Stating that some of their successors behaved like spoilt children by breaking everything and bringing disorder to the house.

\section{Paragraph 13}

Reminding Nigerians of their source/lineage;

Acknowledging that the blood of the great ancestors flow in his veins.

Stating that what is only required is to build on the legacies, to

\section{Paragraph 14} stabilize and uplift Nigeria.

Reassuring that the daunting task is surmountable;

Stating that there is a national consensus that democracy is the route to national development;

Promising to consciously work the democratic system by ensuring that the Executive does not encroach on the duties and functions of the other two arms of government - Legislative and Judicial arms, while the law enforcing authorities are charged to operate within the Constitution.

\section{Paragraph 15}

Promising to rebuild and reform the public service to become more effective and more serviceable;

Promising to charge them to apply themselves with integrity to

\section{Paragraph 16} stabilize the system.

Instructing the legislative arm keep to their brief of making laws and carrying out over-sight functions expeditiously;

Informing that the judicial system needs reform to cleanse itself from its immediate past;

Stating the expectation of the country from the judiciary; Identifying respect for constitution as what can enable the government to serve the country optimally and avoid the confusion.

\section{Paragraph 17}

Proposing to properly clarify the relations between Abuja and the States in order to serve the country better.

Stating that there are constitutional limits to the powers of each of the three tiers of government;

Proposing to check the gross corruption at the local government level. Proposing to ensure responsibility and accountability at all levels of government in the country;

Assuring the check as part of his promise to the Nigerian

\section{Paragraph 18} people.

Acknowledging the support, understanding and cooperation of labour unions, organized private sector, the press and civil 
society organizations in the success of governments of the federation;

Appealing to employers and workers alike to unite in raising productivity so that everybody will enjoy increased prosperity. Acknowledging the Nigerian press to be the most vibrant in Africa.

Appealing to the media, including the social media to exercise its considerable powers with responsibility and patriotism.

Paragraph 19

Appealing for unity;

Acknowledging the terrible state of Nigerian economy;

Stating that the economy requires a careful management to revive;

Proposing to tackle the immediate challenges confronting

Nigeria, especially Boko Haram, the Niger Delta situation, the power and fuel shortages and unemployment;

Proposing to improve the standards of education;

Proposing to improve medicare;

Proposing to improve the dilapidated physical infrastructure.

\section{Paragraph 20}

Assuring that Boko Haram insurgency is immediate;

Acknowledging the progress made in recent weeks by the security forces;

Proposing to relocate the Army Command and Control Centre in Abuja to Maiduguri and remain until Boko Haram is completely subdued.

Proposing to defeat Boko Haram and rescue the Chibok girls

\section{Paragraph 21} and all other innocent persons held hostage by insurgents

Assuring that the government will do what it can to rescue the

Chibok girls alive. Defining the Boko Haram group;

\section{Paragraph 22}

Identifying some of the havocs caused by Boko Haram.

Describing Boko Haram;

Proposing to subdue the group and commission a sociological study to determine the origins, remote and immediate causes of the group movement, its sponsors, the international connections to prevent a recurrence of this evil.

Proposing to fully charge the Armed Forces with prosecuting the fight against Boko haram.

Proposing to overhaul the rules of engagement to avoid human rights violations in operations;

Proposing to improve operational and legal mechanisms so that disciplinary steps are taken against proven human right violations by the Armed Forces; 
Acknowledging that Boko Haram is not only the security issue bedeviling Nigeria.

Identifying other security issues - kidnappings, armed robberies, herdsmen/farmers clashes, cattle rustlings Proposing to erect and maintain an efficient, disciplined well-

\section{Paragraph 23} compensated security personnel.

Acknowledging that the amnesty programme in the Niger Delta is due to end in December;

Proposing to invest heavily in the projects, and programmes currently in place;

Instructing/Calling on the leadership and people in these areas to cooperate with the State and Federal Government in rehabilitating the programmes;

Promising to listen to grievances of fellow Nigerians; Extending his hand of fellowship to all Nigerians.

\section{Paragraph 24}

Identifying the poor power situation as the cause of Nigerian's poor economic performance

Describing the condition of generating only 4,000MW for 180 million people as shameful;

Promising not to allow the power problem to continue;

Proposing to identify the quickest, safest and most cost-effective

\section{Paragraph 25} way to bring light and relief to Nigerians.

Identifying unemployment as stated in his Party's Manifesto as a major problem.

Proposing to attack the problem of unemployment frontally by reviving agriculture, solid minerals, mining as well as credits to small and medium size businesses to kick - start these enterprises.

Proposing to quickly examine the best way to revive major industries and accelerate the revival and development of the

\section{Paragraph 26} railways, roads and general infrastructure.

Acknowledging that Nigeria enjoys so much goodwill abroad now; Acknowledging that there are high international expectations from the messages received from other countries; Stating that Nigeria has a window of opportunity to fulfill the long-standing potential and mission as a great nation.

\section{Paragraph 27}

Advising Nigerians with a quotation from the Shakespeare's Julius Ceasar.

\section{Paragraph 28}

Stating that we have an opportunity in choosing him.

Advising all to use the opportunity. Thanking all. 


\section{Analysis and Discussion}

A close examination of the use of language in Buhari's inaugural speech reveals that ninety-nine acts, categorised into nineteen pragmatic functions, were performed in the speech. In the order of frequency, they include proposing (twenty), acknowledging (seventeen), promising (ten), thanking (ten), stating (nine), assuring (six), remarking (four), appealing (three), reminding (three), instructing/calling (two), advising (two). Others that occurred just once each include saluting, hoping, charging, informing, extending, identifying, describing and defining. The practs were marked by the following pragmatic tools: shared situation knowledge, relevance, reference and inference. The different practs served to achieve four goals which were to reveal the intention of PMB, to admit the existence of some issues and appreciate others, to give direction/directives, and to characterise the problems/issues. Table 1 presents a summary of the identified pragmatic acts, the goals, the frequency and percentage of occurrence in the speech. The table is represented in Figures 2 and 3.

Table 1. Summary of the Pragmatic Acts and Goals

\begin{tabular}{|c|c|c|c|c|c|}
\hline Goal & Frequency & $\%$ & Practs & Frequency & Percentage \\
\hline \multirow{4}{*}{$\begin{array}{l}\text { To Reveal } \\
\text { Intention }\end{array}$} & \multirow[t]{4}{*}{45} & \multirow[t]{4}{*}{$45.5 \%$} & Proposing & 20 & $20.2 \%$ \\
\hline & & & Promising & 10 & $10.1 \%$ \\
\hline & & & Stating & 09 & $9.1 \%$ \\
\hline & & & Assuring & 06 & $6.1 \%$ \\
\hline \multirow{4}{*}{$\begin{array}{l}\text { To Admit and } \\
\text { Appreciate }\end{array}$} & \multirow[t]{4}{*}{32} & \multirow[t]{4}{*}{$32.3 \%$} & Acknowledging & 17 & $17.2 \%$ \\
\hline & & & Thanking & 10 & $10.1 \%$ \\
\hline & & & Remarking & 04 & $4.1 \%$ \\
\hline & & & Saluting & 01 & $1.0 \%$ \\
\hline \multirow{8}{*}{$\begin{array}{l}\text { To Give } \\
\text { Direction/ } \\
\text { Directives to } \\
\text { Nigerians }\end{array}$} & \multirow[t]{8}{*}{14} & \multirow[t]{8}{*}{$14.1 \%$} & Appealing & 03 & $3.0 \%$ \\
\hline & & & Reminding & 03 & $3.0 \%$ \\
\hline & & & Instructing/Calling & 02 & $2.0 \%$ \\
\hline & & & Advising & 02 & $2.0 \%$ \\
\hline & & & Hoping & 01 & $1.0 \%$ \\
\hline & & & Charging & 01 & $1.0 \%$ \\
\hline & & & Informing & 01 & $1.0 \%$ \\
\hline & & & Extending & 01 & $1.0 \%$ \\
\hline \multirow{4}{*}{$\begin{array}{l}\text { To Give } \\
\text { Details on } \\
\text { Issues }\end{array}$} & \multirow[t]{3}{*}{08} & \multirow[t]{3}{*}{$8.1 \%$} & Identifying & 05 & $5.1 \%$ \\
\hline & & & Describing & 02 & $2.0 \%$ \\
\hline & & & Defining & 01 & $1.0 \%$ \\
\hline & 99 & $100 \%$ & TOTAL & 99 & $100 \%$ \\
\hline
\end{tabular}


Figure 2. Graphic Representation of the Goals

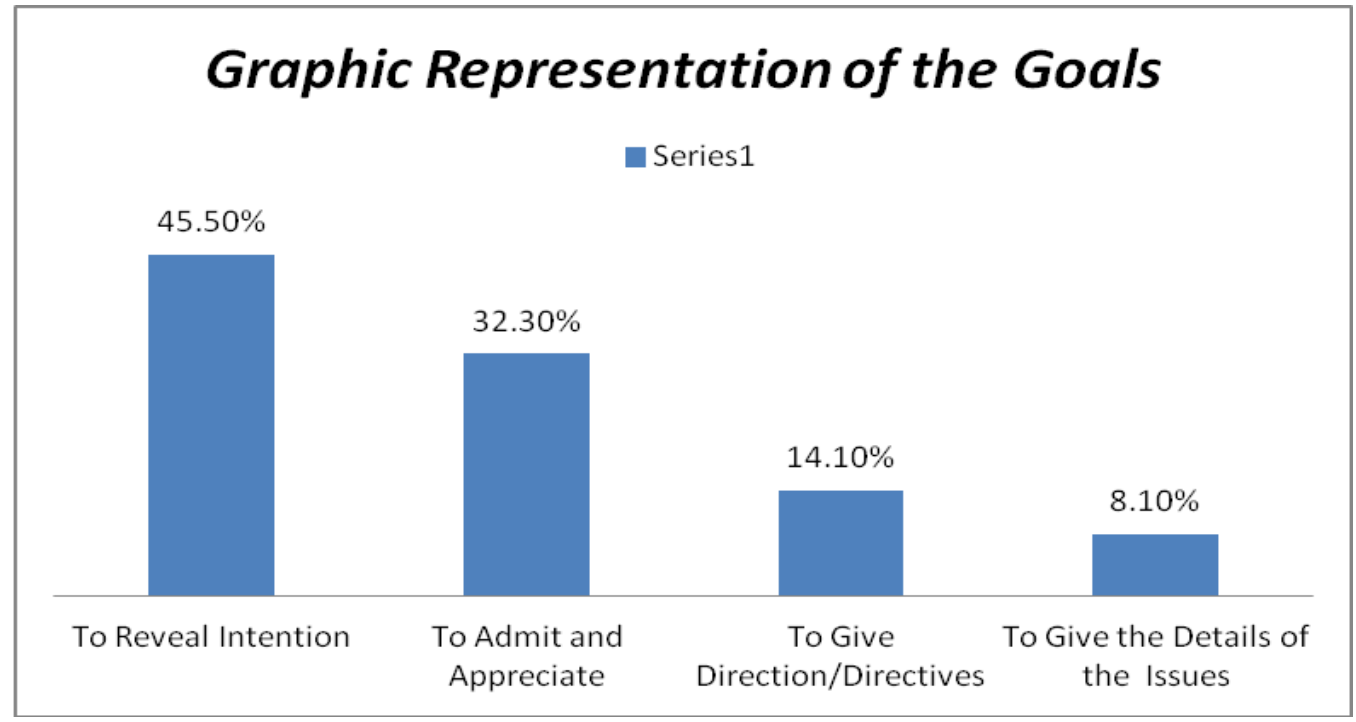

Figure 3. Graphic Representation of the Pragmatic Acts

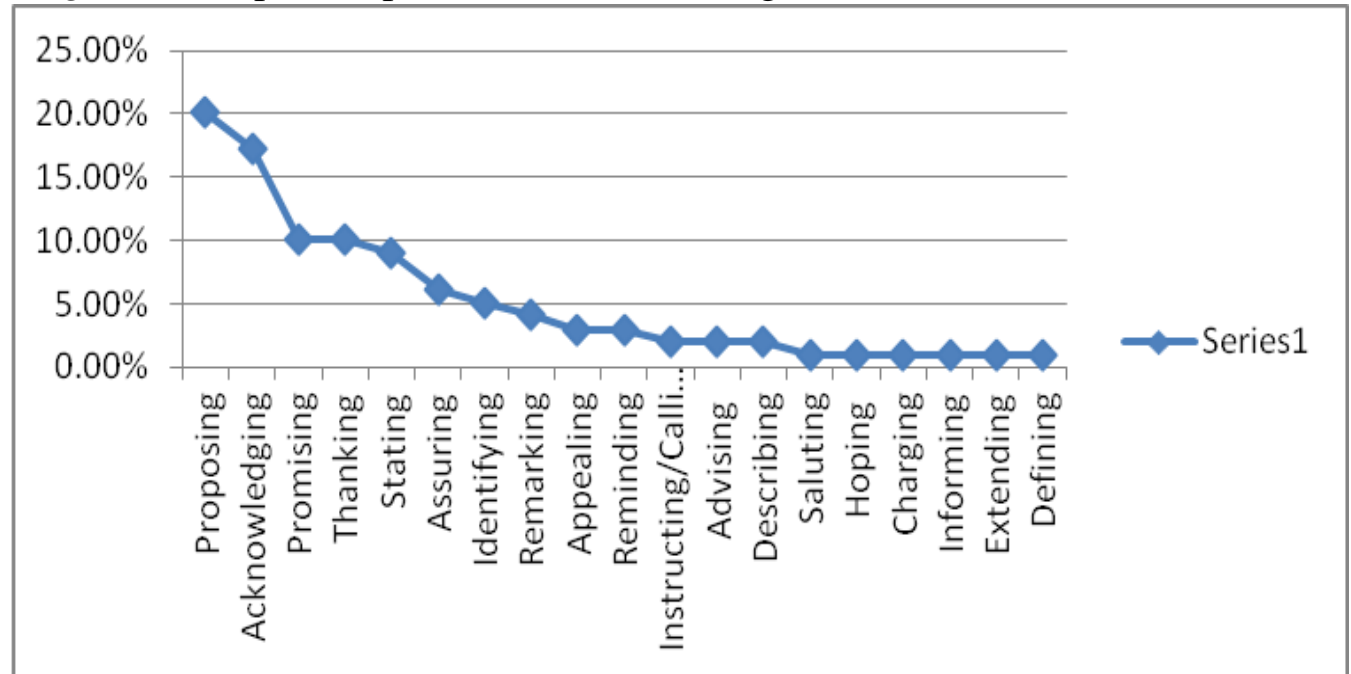

The pragmatic acts were marked with some pragmatic tools such as shared situation knowledge, relevance and inference.

\section{Revealing the Intention}

The goal of revealing intention is explored by PMB using four pragmatic functions - proposing, promising, stating and assuring.

Proposing. The pragmatic act of proposing was mainly used in PMB's IS. The preponderance $(20.2 \%$ occurrence) of the use of the pragmatic function, proposing, can favourably pass the IS for inaugural address of propositions or proposals. The preponderant use of proposing is premised on PMB's desire to swing into action. To repose the required confidence in Nigerians who voted 
for him and those that did not believe in him before, he proposed some of the things to do in office. Also, since he has just taken over governance from PDP which has been in power for 16 years, coupled with the APC's slogan which is "change", PMB believes Nigerians deserve a better life. To him, the better life can only be brought forth by an actual change, and change requires action; hence, the reason for the many proposals. While he proposed some of them as requiring immediate action, he proposed others as long-term plan. The following two extracts (ext.) are samples of the pract of proposing:

Ext. 1: With depleted foreign reserves, falling oil prices, leakages and debts the Nigerian economy is in deep trouble and will require careful management to bring it round and to tackle the immediate challenges confronting us, namely; Boko Haram, the Niger Delta situation, the power shortages and unemployment especially among young people. For the longer term we have to improve the standards of our education. We have to look at the whole field of medicare. We have to upgrade our dilapidated physical infrastructure.

Ext. 2: The most immediate is Boko Haram insurgency. Progress has been made in recent weeks by our security forces but victory cannot be achieved by basing the Command and Control Centre in Abuja. The command centre will be relocated to Maiduguri and remain until Boko Haram is completely subdued. But we cannot claim to have defeated Boko Haram without rescuing the Chibok girls and all other innocent persons held hostage by insurgents.

In the two extracts, the pragmatic function of proposing is mainly used as evident in the introduction of the modal "will", the use of have-verbs, be-verbs and some other action verbs. Most of the issues raised are contextually believed to be relevant to an average Nigerian. Therefore, to achieve the pragmatic act of proposing, PMB uses SSK in relation to the problems which confront Nigerians. He uses REF to refer to the major problems, and REL is brought in as he mentions the relevantly obvious problems. By promising to do this, we also see the psychological act in play wherein many Nigerians are emotionally touched. They would first breathe a sigh of relief that he has, at least, mentioned the problems that require immediate solution; for instance, the security problem has demoralised many Nigerians and rendered thousands homeless.

In some other part of the IS, PMB proposes to properly clarify the relations between Abuja and the states in order to serve the country better; check the gross corruption at all government levels and ensure responsibility and accountability in government; tackle the immediate challenges confronting Nigeria; improve the standards of education; improve medicare; improve the dilapidated physical infrastructure. He also proposes to defeat Boko Haram and rescue the Chibok girls and all others; to fully charge the Armed Forces with prosecuting the fight against Boko haram; to erect and maintain an efficient, disciplined well-compensated security personnel; to invest heavily in the projects and amnesty programmes currently in place; to identify the quickest, safest and most cost-effective way to 
bring light and relief to Nigerians. He proposes to attack the problem of unemployment frontally, and quickly examine the best way to revive major industries and accelerate the revival and development of the railways, roads and general infrastructure.

Promising. Closely related to the pragmatic function, proposing is "promising". Promising (with $10.1 \%$ occurrence) evidently takes some space in the IS. This is where the speechmaker becomes committal. He tells Nigerians some of the things they expect to hear. It is a shared situational knowledge (SSK) that most Nigerian politicians swear to oath and forget doing so minutes later. However, PMB reminds his listeners that he knows what he has done and promises to keep to the oath thus:

Ext. 3: Having just a few minutes ago sworn on the Holy Book, I intend to keep my oath and serve as President to all Nigerians.

To achieve this pragmatic function, PMB uses pragmatic tools such as REL, to aptly present what is relevantly pressing to Nigerians. He also uses REL to identify the public service as one of the problems bedeviling Nigeria. He, therefore, promises to rebuild and reform the public service thus:

Ext. 4: We shall rebuild and reform the public service to become more effective and more serviceable. We shall charge them to apply themselves with integrity to stabilize the system.

Some of the promises made include promising to keep to the oath and serve as President to all Nigerians; promising there will be no paying off old scores because the past is prologue; promising to tackle and fix Nigeria's problems head on. The other promises include promising to work consciously for the democratic system by ensuring that the Executive does not encroach on the duties and functions of the other two arms of government, to listen to grievances of fellow Nigerians; to disallow the power problem from continuing.

Stating. Under this pragmatic function, PMB clearly states some of his objectives as the President. "Stating" takes $9.1 \%$ of the total acts performed in the IS. The use of this function shows PMB's attempt to definitely express the desires of Nigerians as shown in the following Extract where he hinges on the immediate needs of an average Nigerian:

Ext. 5: At home we face enormous challenges. Insecurity, pervasive corruption, the hitherto unending and seemingly impossible fuel and power shortages are the immediate concerns.

It is very relevant to reiterate the key issues bedeviling Nigeria - insecurity, corruption, fuel and power shortages. It is also to state that the economy is in a critically bad shape as at the time of the inauguration of the new government. He, therefore, clearly states that to reassure the emotionally disturbed Nigerians the economy will be carefully revamped. The following Extract attests to this: 
Ext. 6: With depleted foreign reserves, falling oil prices, leakages and debts the Nigerian economy is in deep trouble and will require careful management to bring it round and to tackle the immediate challenges confronting us.

Some of the other aspects of the IS which clearly underscores the stating pract include stating that what is only required is to build on the legacies, to modernise and uplift Nigeria; the observed differences in the methods of our founding fathers is in their tactics or details. Meanwhile he states that some of the successors of the founding fathers behaved like spoilt children by breaking everything and bringing disorder to the house; there is a national consensus that democracy is the route to national development; the expectation of the country from the judiciary. He also states that there are constitutional limits to the powers of each of the three tiers of government; Nigeria has a window of opportunity to fulfill the long-standing potential and mission as a great nation; and that Nigeria has an opportunity in choosing him.

Assuring. No doubt, Nigerians need to know how much they can trust the person of PMB even after being elected. In order to clear their doubts on his personality and the required trust, he needs to assure them that they voted wisely. He, therefore, resorts to assuring them of his promises to deliver the dividends of democracy appropriately; he also speaks to their emotions. For instance, in Extract 7, he assures Nigerians that he will be de-tribalised and non-partisan. Tribalism and partisanship have always given Nigerians concern. His reiteration of non-partisan governance re-assures Nigerians to be calm.

Ext. 7: I belong to everybody and I belong to nobody.

In PMB's chronicle of propositions and assurances, the proposition, promise and assurance to "belong to everybody and to nobody" is very significant to his IS. It is the central aspect of the speech which has become most popular to both listeners and non-listeners. In fact, it is the high point of the speech. The Extract has some pragmatic inference; hence the use of INF requires sufficient SSK to understand the relevance. It also has the deployment of psychological act to address the fearful and sworn enemies of PMB. The Extract personally voiced - VCE by PMB tells much about his readiness to serve all Nigerians and not only his party, APC. While an average member of the People's Democratic Party (PDP) is happy about this, the APC might feel a bit betrayed. However, in the interest of majority of non-partisan millions of Nigerians, it is a fair deal. It is an assurance to be de-tribalised: he is not the President for the northern part of the country alone. It is an assurance to be non-partisan: he is not the President of APC alone, but that of Nigeria and for Nigerians. It is an assurance that his affinity goes beyond ethnic divide, party bias, professional affiliation, among others. 


\section{Admitting and Appreciating}

The goal of admitting and appreciating is explored in PMB's IS, using four pragmatic functions - acknowledging, thanking, saluting and remarking, as discussed presently.

Acknowledging. Acknowledging as a pragmatic function takes $17.2 \%$ of the IS. It sometimes overlaps with the next ranked pract - thanking. The use of acknowledging goes a long way to showing how familiar PMB is with the situation and the historical artifact of Nigeria. To achieve the pragmatic act of acknowledging, he uses REF in making reference to the founding fathers. There is also the use of SSK wherein he does not need to mention the specific roles each of the founding fathers performed. He acknowledges the heroic deeds of the deserving founding fathers. It is given that Nigerians are familiar with the names and their roles in nation building. The use of REL is also seen in how PMB ensures that the reference is relevant and spreads across the regions in Nigeria.

Buhari acknowledges, as evident in Ext. 2, the achievement of the immediate past administration thus: "Progress has been made in recent weeks by our security forces but victory cannot be achieved by basing the Command and Control Centre in Abuja". However, he is equally very fast to add what next to do. This trend is consistent, especially from the second paragraph where he uses some space to appreciate and acknowledge the statesmanship in the former president, Goodluck Ebele Jonathan (GEJ). The use of psychological act is observed here, especially to GEJ and his supporters. To further acknowledge GEJ, the members of his cabinet and allay their fears, PMB uses the pragmatic tool - VCE - to acknowledge thus: "A few people have privately voiced fears that on coming back to office I shall go after them. These fears are groundless. There will be no paying off old scores. The past is prologue". The sufficient allocation of space to acknowledgement shows that PMB is appreciative. It shows that he is not characterised by what an average politician or state governor does in Nigeria upon the assumption of office, especially when the baton is passed from one party to the other.

Some of the other issues acknowledged by PMB include acknowledging his predecessor's statesmanship, his predecessor's cooperation for a smooth transition process, the enormousness of the challenges at home, the unity in the mission of the founding fathers to establish a viable and progressive country. He also acknowledges the great ancestors, the labour unions, organised private sector, the press and civil society organisations, the economy, the security forces. $\mathrm{He}$ acknowledges that Boko Haram is not the only security issue bedeviling Nigeria, that the amnesty programme in the Niger Delta is due to end in December, that Nigeria enjoys so much goodwill abroad now, and that there are high international expectations from the messages received from other countries.

Beyond the acknowledgements of the role of GEJ, PMB gives some space to the founding fathers in an attempt to trace where Nigeria missed the road. In Ext. 8 below, he itemises the names of some of the founding fathers. 
Ext. 8: In recent times, Nigerian leaders appear to have misread our mission. Our founding fathers, Mr. Herbert Macauley, Dr. Nnamdi Azikiwe, Chief Obafemi Awolowo, Alhaji Ahmadu Bello, the Sardauna of Sokoto, Alhaji Abubakar Tafawa Balewa, Malam Aminu Kano, Chief J.S. Tarka, Mr. Eyo Ita, Chief Denis Osadeby, Chief Ladoke Akintola and their colleagues worked to establish certain standards of governance. They might have differed in their methods or tactics or details, but they were united in establishing a viable and progressive country. Some of their successors behaved like spoilt children breaking everything and bringing disorder to the house.

Besides, he goes further to acknowledge the roles of the labour unions and Nigeria press thus:

Ext. 9: However, no matter how well organized the governments of the federation are they cannot succeed without the support, understanding and cooperation of labour unions, organized private sector, the press and civil society organizations. I appeal to employers and workers alike to unite in raising productivity so that everybody will have the opportunity to share in increased prosperity. The Nigerian press is the most vibrant in Africa. My appeal to the media today - and this includes the social media - is to exercise its considerable powers with responsibility and patriotism.

There has been a rare reference by previous administration to the roles of the labour unions and the press in nation building. While the use of REF here speaks to the emotions (Psychological Act) of the concerned parties, PMB may have also used the occasion to woo the labour unions to further support his government and the press to give a good representation; hence he cautions the press "to exercise its considerable powers with responsibility and patriotism".

Thanking and Saluting. Closely related to the pragmatic function, "acknowledging" is "thanking". Both functions sometimes overlap. When an individual is thanked for a good, the individual feels obliged to do more. According to Samuel Johnson, "there are minds so impatient of inferiority that their gratitude is a species of revenge, and they return benefits, not because recompense is a pleasure, but because obligation is a pain". A Vietnamese proverb says "if one receives a plum one must return a peach". PMB, unlike the expectation of many in his speech, decides to show appreciation and gratitude to those that voted him and those that did not. PMB begins the IS by appreciating God, Nigerians, the determination of Nigerians and strong support of friends abroad as seen in Extract 10 below.

Ext. 10: I am immensely grateful to God Who Has preserved us to witness this day and this occasion ... Our journey has not been easy but thanks to the determination of our people and strong support from friends abroad we have today a truly democratically elected government in place. 
He appreciates GEJ for the good he got from him and recommends the type of gesture received from GEJ to other world leaders, as seen in Extract 11 below.

Ext. 11: I would like to thank President Goodluck Jonathan for his display of statesmanship in setting a precedent for us that has now made our people proud to be Nigerians wherever they are. With the support and cooperation he has given to the transition process, he has made it possible for us to show the world that despite the perceived tension in the land we can be a united people capable of doing what is right for our nation.

Buhari also thanks his supporters who believed in him even when the cause seemed hopeless; those who tirelessly carried the campaign on the social media; the other countrymen and women who did not vote for him but contributed to making the democratic culture truly competitive, strong and definitive. He thanks the governments and people of Cameroon, Chad and Niger for committing their armed forces to fight Boko Haram in Nigeria. Finally, he thanks all.

The functional relevance of the pragmatic act of saluting as used in the speech is related to thanking as depicted in Extract 12. Buhari uses the term saluting to acknowledge and praise the electorate for their determination to vote for him and keep vigil in order to ensure that they monitor and protect their vote.

Ext. 12: I salute their resolve in waiting long hours in rain and hot sunshine to register and cast their votes and stay all night if necessary to protect and ensure their votes count and were counted.

Remarking. This pragmatic function is used in the IS to commend Nigerians on the patience so far. Buhari remarks that victory has come finally for voting him in, and that it is time for Nigeria to cherish her democracy and be grateful to God for the freedom. He also comments that the journey has been very rough. This is contained in the first paragraph of the speech thus:

Ext. 13: Today marks a triumph for Nigeria and an occasion to celebrate her freedom and cherish her democracy. Nigerians have shown their commitment to democracy ... we have today a truly democratically elected government in place.

\section{Giving Details on Issues}

The goal of giving details on issues and problems in Nigeria is explored by PMB using three pragmatic functions - identifying, defining and describing, as discussed presently.

Identifying. In the speech, identifying pragmatically functions to establish and indicate the individuals involved in some issues, or issues involved in some events. Identifying which takes $6.1 \%$ of the total acts performed in the speech is used in supporting PMB's claims. In Extract 14, PMB identifies respect for constitution as the secret of democratic success in order to convince Nigerians that he has no plans to act outside the constitution. 
Ext. 14: It is only when the three arms act constitutionally that government will be enabled to serve the country optimally and avoid the confusion all too often bedeviling governance today.

Buhari also identifies as a way of reminder some of the security issues which Nigeria has been suffering from, as contained in Extract 15.

Ext. 15: The spate of kidnappings, armed robberies, herdsmen/farmers clashes, cattle rustlings all help to add to the general air of insecurity in our land.

Some of the other identifications made in the IS include identifying respect for constitution as what can enable the government to serve the country optimally; identifying some of the havocs caused by Boko Haram; identifying other security issues - kidnappings, armed robberies, herdsmen/farmers clashes, cattle rustlings. $\mathrm{He}$ also identifies the poor power situation as the cause of Nigerian's poor economic performance, and unemployment as stated in his Party's Manifesto as a major problem.

Defining and Describing. Whereas the word "define" has to do with describing something correctly and thoroughly, "describe" has to do with saying what something or someone is like by giving details about them. In the IS, PMB uses the definition and description to properly characterise the issues being addressed. In Extract 16, PMB gives a description to the Boko Haram sect and characterise some of the acts they have meted out to innocent Nigerians.

Ext. 16: Boko Haram is a typical example of small fires causing large fires. An eccentric and unorthodox preacher with a tiny following was given posthumous fame and following by his extra judicial murder at the hands of the police. Since then through official bungling, negligence, complacency or collusion Boko Haram became a terrifying force taking tens of thousands of lives and capturing several towns and villages covering swathes of Nigerian sovereign territory.

This act is continued in the next paragraph in the IS. In his further description, he distances the sect from their acclaimed religious affiliation. To him, the sect is not and cannot be said to belong to Islam. This is relevant REL to the REF that Islam is a religion of peace. As evident in Extract 17, he believes that since the sect is made up of people who are mindless and godless, they cannot be said to be practising Islam.

Ext. 17: Boko Haram is a mindless, godless group who are as far away from Islam as one can think of.

\section{Giving Direction and Directives}

The pragmatic acts in this section are specifically meant to achieve PMB's desire to give direction and directives. In order to achieve the goal, he does not only give directives, he also calls on Nigerians and specific group to swing into action in order to achieve the desired success. 
Giving Direction (Appealing/Reminding/Advising/Hoping/Informing). The pragmatic acts in this group are used by PMB to give direction to Nigerians. The first has to do with appeal, where PMB acknowledges and appeals to employers and workers, as contained in Extract 18, to unite in order to increase their productivity for Nigeria to move forward. Also, as contained in Extract 19, he first acknowledges the Nigerian press to be very vibrant, especially in Africa, and appeals to the media to give use its freedom responsibly and patriotically by portraying the country in good light.

Ext. 18: I appeal to employers and workers alike to unite in raising productivity so that everybody will have the opportunity to share in increased prosperity.

Ext. 19: The Nigerian press is the most vibrant in Africa. My appeal to the media today - and this includes the social media - is to exercise its considerable powers with responsibility and patriotism.

The use of reminding is not so prominent in the IS; however, it has $3.0 \%$ occurrence. As a pragmatic function, it is deployed to bridge the possible gap between the president and Nigerians. Buhari uses "reminding" to ensure that both of them are on the same page. In Extract 20, PMB reminds Nigerians of the oath he just took. To Nigerians, he impresses his intention to keep the oath.

Ext. 20: Having just a few minutes ago sworn on the Holy Book, I intend to keep my oath and serve as President to all Nigerians.

In Extract 21, he also reminds Nigerians of the great individuals who have been instrumental to the development on the great Nigeria that was initially conceived. The mention of the names shows PMB pays obeisance to the founding fathers. It tells Nigerians that PMB does not intend to upturn the existing historical foundation of Nigeria, but to build on the solid foundation initially built by them. Beyond the deployment of the pragmatic tool - REL in listing their names, another pragmatic tool - INF is used to draw conclusions on some of the good intentions of Buhari. In Extract 22, he also tries to associate self with the founding fathers of northern extraction by reminding Nigerians of their sources.

Ext. 21: In recent times Nigerian leaders appear to have misread our mission. Our founding fathers, Mr. Herbert Macauley, Dr. Nnamdi Azikiwe, Chief Obafemi Awolowo, Alhaji Ahmadu Bello, the Sardauna of Sokoto, Alhaji Abubakar Tafawa Balewa, Malam Aminu Kano, Chief J.S. Tarka, Mr Eyo Ita, Chief Denis Osadeby, Chief Ladoke Akintola and their colleagues worked to establish certain standards of governance. They might have differed in their methods or tactics or details, but they were united in establishing a viable and progressive country. Some of their successors behaved like spoilt children breaking everything and bringing disorder to the house. 
Ext. 22: Furthermore, we as Nigerians must remind ourselves that we are heirs to great civilizations: Shehu Othman Dan fodio's caliphate, the Kanem Borno Empire, the Oyo Empire, the Benin Empire and King Jaja's formidable domain. The blood of those great ancestors flow in our veins. What is now required is to build on these legacies, to modernize and uplift Nigeria.

The other practs which give direction in the IS with minimum percentage of occurrence include advising (2.0\%), hoping (1.0\%) and informing (1.0\%). Buhari uses advising to tell Nigerians what their roles should be in the new administration. He uses literary allusion from William Shakespeare's Julius Caesar as contained in Extract 23.

Ext. 23: Our situation somehow reminds one of a passage in Shakespeare's Julius Ceasar. There is a tide in the affairs of men which, taken at the flood, leads on to fortune; Omitted, all the voyage of their life; Is bound in shallows and miseries. We have an opportunity. Let us take it.

Buhari advises Nigerians not to misuse the opportunity he is presenting by offering himself to be of service. PMB also uses the pragmatic function hoping - as contained in Extract 24, to direct politicians to embrace gracious acceptance of the outcome of political elections regardless of which way the pendulum swings.

Ext. 24: I hope this act of graciously accepting defeat by the outgoing President will become the standard of political conduct in the country.

Finally, he gives information, as contained in Extract 25, which he accepts to be directly relevant to the judicial system's personnel.

Ext. 25: The country now expects the judiciary to act with dispatch on all cases especially on corruption, serious financial crimes or abuse of office. It is only when the three arms act constitutionally that government will be enabled to serve the country optimally and avoid the confusion all too often bedeviling governance today.

Calling to Action (Charging/Instructing/Calling). The pragmatic acts in this group are used by PMB to call on Nigerians to be proactive. The first has to do with charging Nigerians. Charging, which is represented by $1.0 \%$ of occurrence, for instance, in Extract 26, is used to charge Nigerians to embrace hope and success, while they de-emphasise pessimism and defeatism.

Ext. 26: Nigerians will not regret that they have entrusted national responsibility to us. We must not succumb to hopelessness and defeatism. We can fix our problems.

Instructing/Calling is used as a pragmatic function to call others to duty. It takes $2.0 \%$ of the total occurrences of acts in the IS. In Extract 27, it is a call in 
the form of instruction to the legislative arm to discharge their duty as expected and very fast too. Also in Extract 28, the call goes to Nigerians who are leaders of the Niger Delta to join hands to further entrench rehabilitative programmes in the amnesty zone.

Ext. 27: For their part the legislative arm must keep to their brief of making laws, carrying out over-sight functions and doing so expeditiously.

Ext. 28: I call on the leadership and people in these areas to cooperate with the State and Federal Government in the rehabilitation programmes which will be streamlined and made more effective.

\section{Conclusion}

The examination of the Inaugural Speech of President Muhammadu Buhari as delivered on 29th May, 2015 reveals the use of different pragmatic acts to achieve different goals. Beyond the fact that the speech highlights the intentions and goals of the President as promised during the electioneering campaign, nineteen pragmatic acts were identified from the total ninety-nine acts found in the speech, and were meant to reveal the intention of PMB, admit the existence of some issues and appreciate others, give direction/directives, characterise the problems/issues. Meanwhile the following pragmatic acts aided the achievement of the goals: proposing promising, stating, assuring, acknowledging, thanking, remarking, saluting, appealing, reminding, instructing/calling, advising, hoping, charging, informing, extending, identifying, describing and defining. In addition, shared situation knowledge, relevance, reference, inference were the pragmatic tools deployed to mark the pragmatic acts.

This paper has added to the exiting body of knowledge on rhetoric, and has added to the understanding of the political agenda of President Muhammadu Buhari. All the goals were geared towards Nedashkivska's (2006, p. 41) assertion on the view that the presidential speech evokes "a linguistic activity that establishes the relationship between the president, the society and its members". This particular inaugural speech was able to allay the anxiety of many Nigerians and promote peaceful atmosphere, especially based on the propositions, promises, acknowledgements and appreciation of the immediate past president and other political opponents. The IS was able to express PMB's agenda, reaffirm his electioneering campaign promises and the goals to achieve in office. It also disseminates information, douses tension generated from the campaign and election period. His assurance to be de-tribalised and non-partisan in the sentence "I belong to everybody, I belong to nobody" is equally a stimulant which summarises his intention as the new President of the Federal Republic of Nigeria to the citizenry. 


\section{References}

Adegbija, E. (1995). I, Major General X: Discourse Tacts in Military Coup Speeches in Nigeria. Text: An Interdisciplinary Journal of the Study of Discourse, 15(2), 253-270.

Adetunji, A. (2006). Inclusion and Exclusion in Political Discourse: Deixis in Olusegun Obasanjo's Speeches. Journal of Language and Linguistics, 5(2), 177-191.

Adetunji, A. (2009). Acts in the Second Inaugural Address of Nigeria's President Olusegun Obasanjo and America's President George. In A. Odebunmi, A. E. Arua, \& S. Arimi (Eds.), Language, gender and politics: A Festschrift for Yisa Kehinde Yusuf (313-325). Lagos: Concept Publications Ltd.

Adeyanju, D. (2002). Sociolinguistics: An Introductory Insight. In S. Babatunde \& D. Adeyanju (Eds.), Language, Meaning and Society: Papers in Honour of E.E. Adegbija at 50. Ilorin: Haytee Press.

Austin, J. L. (1962). How to Do Things with Words. Oxford: Oxford University Press.

Ayeomoni, M. O. (2005a). A Linguistic-Stylistic Analysis of Some Political Speeches of Past Nigerian Military Rulers. Papers in English and Linguistics, 6, 1-13

Ayeomoni, M. O. (2005b). Grapho-Syntactic Analysis of Selected Political Speeches of Some Nigerian Military Heads of State. Awka Journal of Linguistics and Languages, 1, 1-9.

Ayeomoni, O. M. \& Akinkuolere, O. S. (2012). A Pragmatic Analysis of Victory and Inaugural Speeches of President Umaru Musa Yar'Adua. Theory and Practice in Language Studies, 2(3), 461-468.

Ayoola, K. (2005). Interpreting Nigeria's Political Discourse: A Study of President Olusegun Obasanjo's July 26, 2005 Address to Nigeria's National Assembly. Papers in English Linguistic, 6, 1-13.

Chilton, P. (2004). Analysing Political Discourse: theory and practice. London: Routledge.

Crystal, D. (1971). Linguistics. Harmondsworth: Penguin Books Ltd.

Halliday, M. A. K. (1978). Language as a Social Semiotic: The Social Interpretation of Language and Meaning. London: Edward Arnold.

Joseph, J. E. (2006). Language and Politics. Edinburgh University Press Ltd.

Josiah, U. E. \& Johnson, S. E. (2012). Pragmatic Analyses of President Goodluck Jonathan's and President Barack Obama's Inaugural Addresses. International Journal of Humanities and Social Science, 2(12), 261-278.

Mey, J. L. (2001). Pragmatics: An Introduction (2nd ed.). Oxford: Blackwell.

Nedashkivska, A. (2006). Presidential Speech and Processes of Language Democratization in Contemporary Ukraine. Australian Slavonic and East European Studies, 20(1-2), 39-65.

Odebunmi, A., \& Oni, F. (2012). Wording the Gloom of an African Democracy: Lexical Choices and Cognition in Nigeria's President Olusegun Obasanjo's Inaugural Speeches. Ibadan Journal of English Studies, 8(1), 31-48

Oha, O. (1994). Language in War Situation: A Stylistics Study of the War Speeches of Yakubu. Gowon and Emeka Ojukwu (Unpublished doctoral dissertation). University of Ibadan, Nigeria.

Okpanachi, M. I. (2009). Discourse analysis of President Obasanjo's national address on the Nigeria Labour Congress on 8th October, 2003. In A. Odebunmi, A. E. Arua, \& S. Arimi (Eds.), Language, gender and politics: A Festschrift for Yisa Kehinde Yusuf (313-325). Lagos: Concept Publications Ltd. 
Olaniyi, K. O. (2010). A Pragmatic Analysis of President Umar Yar'adua's Inaugural Speech of 29th May, 2007. Journal of the Nigeria English Studies Association, 13(2), 45-59.

Opeibi, B. O. (2009). Discourse, Politics and the 1993 Presidential Election Campaigns in Nigeria. Lagos: Nouvelle Communications Ltd.

Osisanwo, A. (2009). Slangy Expressions as Communicative Tools among University Undergraduates. In D. Adeyanju (Eds.), Sociolinguistics in the Nigerian Context (206-222). Germany: Lincom Europa Publishers.

Osisanwo, A. (2010). Language, Politics and Development: A Lexico-Semantic Analysis of Selected Political Posters. International Journal of Languages and African Development, 2(1), 159-176.

Osisanwo, W. (2003). Introduction to Discourse Analysis and Pragmatics. Lagos: Femolus-Fetop Publishers.

Yusuf, Y. K. (2003). Dysphemism in the language of Nigeria's President Olusegun Obasanjo. In S. Makoni \& V. H. Meinhof (Eds.), Africa and Applied Linguistics (104-119). Amsterdam, Philadelphia: John Benjamins. 